$$
\text { studie l }
$$





\title{
Verzologické výskumy v Čechách a na Slovensku (Pocta Jiřímu Levému)
}

\author{
Ladislav Franek
}

\section{ABStract}

\section{The Study of Verse in Czechia and Slovakia (A Homage to Jiří Levý)}

The legacy of the Czech and Slovak study of the poetic structure from the 1930s to the 1960s (J. Mukařovskýs “semantic gesture”, M. Bakoš key function of the poetic rhythm). Their synthetic character under the influence of the principles of modern linguistics and Russian formalism. Literary history and historical poetics. The deepening of these starting points from the point of view of the needs of interliterary research. The objectivizing-logical criterion in respecting the specifics of national metrical systems. The contribution of J. Levý and his influence on the Slovak school of translation. His reflections upon a more integral perception of stylistic-rhythmical shifts in literary translation. The diversification of individual epistemological models according to the specificity of respective scholarly environments. The theory of literary communication in the inter-play of theory and empiricism in the works by A. Popovič. Slovak comparative literature research (D. Durišin) and its place in inter-literary research of L. Franek (the monograph Štýl prekladu, 1997; finished already in 1975). Inspirational exploration of the differences in the development of national literatures (French and Slovak). The striving for the unity of immanence and transcendence. Comparison with other metrical (e.g., Spanish) models. The violent interruption of the continuity of such research after the so-called "normalization" in the 1970s and the resulting problems in returning to these research models after 1989.

\section{KEYWORDS}

Czech and Slovak literary studies, semantic gesture, poetic rhythm, structural poetics, historic poetics, translations analysis (Paul Claudel).

\section{KLúčové SLOVÁ}

Česká a slovenská literárna veda, sémantické gesto, básnický rytmus, štruktúrna poetika, historická poetika, analýza prekladov (Paul Claudel). 
Azda netreba pripomínat', že výskum literatúry ponúka možnosti mnohorakých metód a prístupov. Ak sa teda dnes pri príležitosti významného jubilea Jiřího Levého vraciame $\mathrm{k}$ výsledkom českých a slovenských bádatel’ov, ktorí v podstate už v prvej polovici dvadsiateho storočia vystúpili s požiadavkou zvedečtenia literárnych metód, nápadne vystúpi do popredia moment interdisciplinárnosti, viacrozmerného spojenia alebo prelínania rozličných aspektov.

Práve daný moment sa v niektorých vývinových obdobiach literárnej vedy stáva hlavným ciel'om, pričom ho určuje nielen individuálne nezávislé stanovisko, ale aj aktívna spolupráca s inými predstavitel'mi podobnej orientácie. Vzniká tak jednotiaci a zároveň diferenciačný model, zásluhou ktorého sa literárna tvorba podrobuje rôznorodému spektru obohacujúcich i prehodnocujúcich pohladov. Sú založené na skĺbení historických, vývinovo-teoretických a komparatívnych postupov a ich prvoradým zámerom je dospiet' $\mathrm{k}$ umenovednej syntéze. Spojenie synchrónie a diachrónie potvrdzuje relačnú alebo korelačnú podstatu pracovnej metódy. Hádam nebudem predbiehat môj výklad určitých rozdielností v českej a slovenskej metodike verzologických výskumov, ak poviem, že obdobné úsilie sa vyznačuje viacerými spoločnými znakmi, ktoré však svojou komplementárnostou nevylučujú ani odlišné stanoviská k predmetu bádania.

$\mathrm{Z}$ tohto hladiska možno pokladat prínos Jiřího Levého za zásadný, originálny i nad’alej podnetný. Umocňuje ho skutočnost', že v jeho prípade nejde o vyhranený postoj laboratórne uzavretého vedca, ale že jeho pôsobenie má široký zmysel didaktický. Zo skúsenosti mojej vlastnej pedagogickej práce môžem potvrdit', že akýkolvek komplexnejší vstup do oblasti porovnávacej verzológie sa nezaobíde bez dôkladného štúdia Levého teoreticko-analytických princípov. Všestranne totiž poskytujú klúč k tomu, aby národná literatúra v konfrontácii s cudzími literatúrami našla svoj vlastný priestor $\mathrm{v}$ možnosti presahu jednotlivých autorských poetík smerom $\mathrm{k}$ historicko-vývinovému sledovaniu ich špecifických prejavov.

Spoločným menovatel'om Levého výskumnej aktivity je systematicky proklamovaný zretel' na jazyk a jeho štruktúrne vlastnosti. V podobnom duchu vyznieva odkaz na definíciu prekladu z pera jeho predchodcu Otokara Fischera, ktorý „teorii překladu pokládá za disciplinu lingvistickou nebo literárněvědnou“. V Levého chápaní však ide o čosi viac. Síce sám uznáva, že do „kompetence jazykovědy patří srovnávácí zkoumání dvou jazykových systémů“, čo je podla neho „samozřejmým předpokladem překladatelovy řemeselní výzbroje“, na druhej strane vidí pôsobenie literárneho vedca v nevyhnutnom presahu porovnávacej gramatiky a štylistiky do kritického postoja. Hodnoty diela sa v dobovo príznačnom realistickom vnímaní uňho odvíjajú od vztahu „k životní 
problematice překladatelova prostředí, volby interpretačního stanoviska, přetransformování uměleckých skutečností v něm zobrazených“ (LEVÝ 1963: 49).

Vzhladom na dve konkretizácie toho istého diela sa rodí Levého pojem podvojnej štruktúry preloženého diela a jeho funkcie v národnej kultúre, čo je podla neho vlastným predmetom literárnej vedy. Reprodukčná úloha umeleckého prekladu, detailne rozpracovaná v knihe Umění prekladu, teda vyzdvihuje nezanedbatelný vplyv vnútorných a vonkajších kontextov literárneho diela, psychologických, spoločensko-kultúrnych alebo ideových, pretože majú rovnocenný význam pri hodnotovej analýze umeleckého prekladu.

Dozaista s plným vedomím tejto funkcie pristupuje Jiř́i Levý k zákonitej redukcii spomenutých činitel’ov, aby v záujme exaktnosti zdôraznil materiálové skúmanie básnických prekladov, v snahe čo najobjektívnejšie zachytit a charakterizovat odchýlky básnického prekladu diela v jazyku češtiny.

$\mathrm{K}$ tomu ho vedie poznatok, že logická analýza vnútornej stavby básnického jazyka vyžaduje venovat' zvýšenú pozornost' pôsobeniu tých činitel'ov umeleckej tvorby, ktoré boli v literárnovednom skúmaní dovtedy najviac zanedbávané. Týka sa to v prvom rade rozdielov v gramatickej, fonetickej, sémantickej a morfologickej stránke jazykov a ich pôsobenia na výsledný tvar básnického prekladu. Za týmto účelom sa J. Levý mohol opierat’ o viaceré podnety českej literárnej vedy, pričom túto problematiku skúmal na pozadí vývinu národného básnictva. Dialo sa tak súbežne v Čechách i na Slovensku hlavne v tridsiatych rokoch dvadsiateho storočia, a to zásluhou dvoch najvýznamnejších predstavitelov - Jana Mukařovského a Mikuláša Bakoša.

Napriek tomu, že v koncepcii obidvoch literárnych vedcov možno vypozorovat nemálo spoločných čŕt, je zaujímavé s odstupom času sledovat', v čom sa ich modely navzájom odlišujú a, predovšetkým, v čom u nich rozhodujúcu úlohu zohráva nerovnaká miera inšpiratívnosti inonárodných prameňov pre utváranie epistemologického kréda. Základným zistením je vcelku rovnocenná pozornost', akú Mukařovský i Bakoš venujú funkcii básnického jazyka a jeho historickému vývinu v českej a slovenskej literatúre. I ked', ako vieme, Mukařovského záujem je zo slohovo-druhového hladiska podstatne širší, obidvaja interpretátori si uvedomovali, že sama podstata básnického diela umožňuje hodnoverné sledovanie premenlivosti jeho komponentov a estetickej funkcie vo vývine národnej literatúry.

Báseň je teda svojou štruktúrnou povahou najlepšie uspôsobená na to, aby primárnym dôrazom na jazykový oznam sa mnohostranne ukázal celistvý charakter výstavby literárneho textu v jeho konkrétnom vyjadrení. Povedzme si bližšie, ako k tomu dochádza v obidvoch koncepciách. 
Najprv sa javí ako závažný fakt, že Mukařovského zámerom bolo zrušit protikladné hranice medzi jazykom básnickým a jazykom praktickým, a to hladaním tzv. prechodových štádií, aby sa dala komplexnejšie zachytit aktualizácia jednotlivých prvkov v básnickej reči. $\mathrm{K}$ tradičnému literárnohistorickému hl’adisku uňho pristupuje hladisko vývinové, tak ako ho vo svojich prácach proklamovali ruskí formalisti sústredení na jazykovú stránku básnického pomenovania. Podobná koncepcia však zároveň rátala s potrebou obracat sa k nadjazykovým príznakom básnického prejavu, k empirickej skutočnosti sociologickej, psychologickej, kultúrnej či širšie kulturologickej. Napríklad pri porovnaní kompozičných postupov J. Vrchlického a K. H. Máchu, vývinové zmeny vo veršovej štruktúre Mukařovský sleduje aj v pomere k spoločnosti, k českému národnému básnictvu a podobne.

Vcelku povedané, sledovanie vzájomných súvislostí medzi slovom, jeho zvukovou, eufonickou, syntaktickou alebo intonačnou realizáciou a významom (Mukařovského dôraz na „sémantické gesto“), ked’ slovo vd’aka svojej mnohovýznamovosti a nestálosti, ako pozoruje u Máchu, nadobúda charakter jazykového znaku alebo symbolu, svedčí o osobitom prelínaní poznatkov z histórie a teórie literatúry s poznatkami $z$ historickej poetiky.

$\mathrm{Na}$ druhej strane je príznačné, že vo veršových výskumoch $\mathrm{M}$. Bakoša zaujíma klúčové postavenie básnický rytmus a premenlivost jeho funkcie vo vývine slovenskej poézie (porov. Vývin slovenského verša od školy Štúrovej, prvé vydanie je z r. 1939, d’alšie, prepracované, z rokov 1949, 1966). Na rozdiel od primárneho vztahu medzi slovom a významom, z ktorého vychádzal Mukařovský, v tesnejšej súvislosti s vývinom umeleckej avantgardy a prácami ruských formalistov (sprístupnil ich vlastným výberom uverejneným pod názvom Teória literatúry, 1941) Bakoš dôslednejšie uprednostňoval spojenie literárnej teórie a historickej poetiky. Tradičné poňatie literárnej teórie zároveň v zhode s Mukařovským prehodnotil popretím statickej normatívnosti, a to hladaním precízne formulovanej nadstavby, v ktorej by jednotlivé zložky verša vystupovali v dynamickej súvztažnosti ako odraz vývinu slovenskej poézie.

Ked porovnáme obidva prístupy $z$ hladiska najvšeobecnejších čŕt umenovednej poetiky, zistíme, že Mukařovský sa zhoduje $s$ Bakošom v otázke vnútroliterárneho vývinu národného verša. Vztłahuje sa to na fakt prevahy pravidelnej metrickej organizácie nad intonačno-syntaktickým členením verša, ako to pozorujeme v Čechách u lumírovcov a na Slovensku u príslušníkov hviezdoslavovskej generácie. Dôsledné využívanie jambu vedie M. Bakoša, zrejme pod priamym vplyvom J. Mukařovského, k tvrdeniu o potrebe básnikov obidvoch generácií 
zastierat' veršový pôdorys uvol'nenou syntakticko-intonačnou stavbou veršov. Treba dodat', že k metodickému zblíženiu dochádza na platforme historickej poetiky budovanej na prísnom logicko-kauzálnom výklade. Podobný objektivistický prístup je však u Bakoša, dôsledne rešpektujúceho funkčné hladisko, v celej jeho práci o slovenskom verši v podstate záväzný (rozboru uvedených rozdielov sa detailnejšie venujem v štúdii Jan Mukařovský a Mikuláš Bakoš - koncepčné rozdiely (Interdisciplinárnost’ v symbióze literárnej vedy a umenia II, 2016, 59-66).

Nebude bez zaujímavosti uviest', že k podobnému výsledku, ktorý však zároveň upozorňuje aj na odlišnosti v istom zmysle príbuzných koncepcií, obaja dospievajú vd’aka sústredenému kontaktu s ruským formalizmom v tridsiatych rokoch. Dôležité je však zistenie, že na Slovensku sa princípy historickej poetiky hlavným pričinením M. Bakoša obnovujú začiatkom šest’desiatych rokov. Dôkazom je dôraz, ktorý sám programovo kladie na spojenie literárnej teórie a historickej poetiky. V slobodnejších podmienkach zápasu o autonómnost̉ literárnej vedy toto spojenie malo podporovat tvorbu takých metód, ktoré by na rozdiel od tradičných východísk s prevahou geneticko-empirických a historických východísk vyzdvihovali dovtedy málo využívanú funkčnost’ modelov založených na typológii. Tieto modely boli orientované aj na prozaické a dramatické formy, na ich druhovo-slohovú premenlivost́ v slovenskej literatúre. Nemožno pokladat’ za náhodu, že podobná koncepcia, ktorá mala znaky kolektívneho úsilia slovenských literárnych vedcov združených v novovzniknutom Ústave svetovej literatúry a jazykov SAV (1964), podnecovala ich aktivitu vo viacerých smeroch, či už išlo o oblast' genológie, komparatistiky alebo porovnávacej verzológie. A to i napriek tomu, že Mikuláš Bakoš v tých časoch prízvukoval aj možnosti hladania nových ciest. Jeho cielom bola istá rehabilitácia tradičných prístupov v nadväznosti na zaužívané historické a zároveň kritické postupy. Prispieval $\mathrm{k}$ tomu predovšetkým objavno-novátorský vývin modernej európskej a svetovej literatúry, ktorý v súlade s potrebným zvedečtením analyticko-teoretickej práce mohol viest' $\mathrm{k}$ vítanému zovšeobecneniu a zároveň $\mathrm{k}$ istej komplementarizácii umeleckých a literárnovedných kritérií a princípov.

Vo sfére verzologických porovnávacích výskumov bolo možné takýmto spôsobom plodne nadviazat’ na prácu niektorých slovenských bádatel’ov. Konkrétne na knihu Viktora Kochola Slovo a básnický tvar (1966), ktorej predmetom bolo prekladanie slovenských romantických básnikov do češtiny a ruštiny a opačne. Uplatňuje sa $v$ nej v istom zmysle predstava štruktúrnych vlastností poézie. I ked v otázkach formálno-vývinových zákonitostí, ako konštatuje Popovič v knihe Preklad a výraz (1968), Kochol ešte nepracuje dôkladnejšie s bakošovským 
modelom, na tradičnom podhubí s ohlladom na parciálnu analýzu jednotlivých motívov uplatňuje princíp funkčnej náhrady, respektíve substitúcie výrazových prostriedkov.

Na báze historickej poetiky stojí podobným spôsobom aj Viliam Turčány, využívajúci podnety z vlastnej básnickej tvorby a prekladatel’skej práce. V rozsiahlej štúdii K poetike Hviezdoslavových prekladov dospieva k názoru, že z porovnania originálu a prekladatel’ových odchýlok možno vyvodit vztłah k zobrazovanej skutočnosti, ktorý prekladatel’ uplatňuje vo vlastnej tvorbe. Hovorí: „Presne stanovený text predlohy núti prekladatel'a k zápasu s takými tematickými okruhmi a tvárnymi prostriedkami, ktoré by možno už i pre jazykové tažkosti obišiel; tuná musí pristúpit až k najkrajnejším medziam svojej poetiky“ (TURČÁNY 1960/1961).

Nebude od veci uviest', že Anton Popovič podrobil jeho koncepciu postavenú na schval’ovaní alebo zamietaní prvkov štruktúry originálu v akte reči (ponechávajúci a odlišovací princíp) kritickému zhodnoteniu. Pramení z imanentistických zásad historickej poetiky, i ked', na strane druhej, súhlasí s Turčányho tvrdením, že „doslovnost' môže byt’ esteticky príznakovým momentom prekladov z jazykovo príbuzných literatúr a že treba s ňou vlastne počítat"“ (POPOVIČ 1968: 23).

Z podobných zorných uhlov nazerá Popovič tiež na dôrazne normatívne chápanie umeleckého prekladu v koncepcii Dionýza Ďurišina (Problémy literárnej komparatistiky, 1967). Jeho vymedzenie komparatistiky na existenciu literárnych vztahohov ako prekladatel'ského aktu (vo vztahu k individuálnej prekladatel'skej poetike, $\mathrm{k}$ dobovej hierarchii hodnôt i vztahu predlohy k prekladu) pokladá za nedostatočnú, pretože neberie do úvahy „existenciu istej literárnej štruktúry“, a pri zanedbávaní synchrónie, t.j. hĺbkovej štruktúry textu, sa podl'a neho obchádza teoreticky systematické chápanie prekladu (IBID.: 24). Treba však dodat', že Ďurišin na rozdiel od Popoviča systematickejšie využíva pojem vývinový rad národných literatúr, ktorý som sa usiloval začlenit aj do mojich vlastných výskumov.

Štruktúrne chápanie textu Popovič na druhej strane pozoruje práve v teoretickej sústave umeleckého prekladu, ktorej tvorcom je J. Levý v knihe Umění překladu. Dokladá to slovami: Levý „vel’mi úspešne spojil tradície a postuláty literárnovedného štrukturalizmu so súčasnými lingvistickými postulátmi. Tým vytvoril možnost' skúmat preklad ako jazykový fenomén, ktorý plní estetickú funkciu“. Levého prínos sa podla neho odráža „v prísnom scientizme, v novopozitivistickom dôraze na logickú analýzu skúmaného objektu“" (IBID.: 26).

Z môjho stanoviska však Popovič popri kritike ideovo-realistických východísk Levého nedocenil výrazne osobnostné kvality českého literárneho vedca, ktorý 
bol schopný obohatit hĺbkovú štruktúru porovnávaných veršov o mnohé aspekty, ktoré do tých čias na Slovensku citel’ne chýbali. Kedže zakaždým ide o dynamické chápanie veršovej štruktúry, rozširuje sa Levého zorný uhol o systematické poznávanie činitel’ov, ktoré sú na rozdiel od Bakošovej metodickej vecnosti predovšetkým z psychologického hladiska (vzt’ah zvuku a významu, syntaktickej stavby k prízvukovaniu) mnohostranne podnetné pre analýzu špecifických čŕt národných jazykov, či už češtiny vo vztahu k angličtine, francúzštine, španielčine, ruštine, polšstine alebo antickým jazykom, zatial' čo u slovenských verzológov je analytický záber užší, predovšetkým vo vztahu k západným jazykom. Celkové kvality J. Levého napriek tomu A. Popovič v závere svojho hodnotenia vystihol presne: „Levý ako prvý u nás nastolil mnohé otázky teoretickej povahy, ako napríklad problém analýzy prekladu ako interpretácie textu alebo otázky posunu v štýle prekladu. Levého koncepcia zasahuje do budovania slovenskej prekladatel’skej teórie podnecujúco a doplňujúco.“ Zásluhou toho, dodáva, „tvorí organickú súčast’ slovenského literárnovedného myslenia“ (IBID.).

V súvislosti s tým, ako sa na Slovensku v šest'desiatych rokoch s nemalým prispením J. Levého vytvárala koncepcia umeleckého prekladu, treba uviest́ relevantný poznatok. Do istej miery sa dotýka viacrozmerného prístupu A. Popoviča v knihe Preklad a výraz (1968), v ktorej sa podla môjho názoru slovenskému vedcovi podarilo skĺbit poznatky z domáceho historického a kritického dedičstva s niektorými štrukturalistickými zásadami. Na tradičnejšom podhubí totiž prejavil schopnost' citlivo vnikat do celistvej povahy veršovej štruktúry, o čom zároveň svedčia viaceré jeho štúdie využívajúce teóriu literárnej komunikácie na empirickom základe.

Nemožno si pri tom neuvedomit’, že na Slovensku i v Čechách v danom období zohrávalo nezanedbatel'nú úlohu pretrvávajúce pôsobenie tradičných pohladov na literatúru. Hoci ideologický tlak na tvorbu štruktúrne zacielených projektov sa javil ustavične silný, autorita M. Bakoša umožňovala hlavne na akademickej pôde nastupujúcim vedeckým ašpirantom i mladým básnikom vstrebávat nové poznatky o verši. Na druhej strane mal M. Bakoš plné pochopenie pre fundovanú literárnu kritiku v spojitosti so znalostami z histórie, nielen slovenskej literatúry. Takúto symbiózu preňho stelesňoval Jozef Felix, ktorý sa už v medzivojnovom období v bezprostrednejšom dotyku s dielom F. X. Šaldu intenzívne zaoberal celým spektrom národného a inonárodného dedičstva, s hlavným zameraním na francúzsku literatúru. Diapazón jeho záujmov bol mimoriadne široký, počnúc Dantem cez Villona, Rabelaisa, a končiac významnými zjavmi moderných románskych literatúr (popri Rollandovi, Saint-Exupérym tu 
figurovali aj Unamuno alebo Cervantes). Ťažiskom Felixovho pôsobenia bol dôraz na univerzálne posolstvo obsiahnuté vo vrcholkoch národných literatúr, čo dokumentoval početnými prekladmi a komentármi vo forme článkov, recenzií alebo doslovov $\mathrm{k}$ preloženým dielam.

Pripomeňme si, že kritický postoj J. Felixa mal nemalý korigujúci vplyv na slovenskú literatúru, ktorú zhodnocoval na pozadí autonómnosti kréda umeleckej tvorivosti. Tým sa vlastne zbližoval s obrodeneckým pôsobením Josefa Jungmanna, ktorý prekladmi Chateaubriandovej Ataly alebo Miltonovho Strateného raja mal už dávnejšie rovnaký úmysel povzniesť českú literatúru na úroveň štylisticky a esteticky náročnejších diel západnej literatúry. Felixova kritika bola namierená napríklad voči slovenským nadrealistom, upozorňovala na egocentrické zahl'adenie sa do seba, na hl’adanie neskutočných „anjelských zemí“, alebo na privel'kú dávku plagiátorstva či imitatívnosti vo vztahu k cudzím vzorom (Giono, Ramuz). Ked’že išlo vždy súbežne o Felixovu rozmanitú a erudovanú prekladatel’skú prácu, vychádzali z nej mnohé podnety pre užitočnú spoluprácu so slovenskými prekladatelmi poézie. Potvrdzujú to aj slová V. Turčányho, ktorý napísal: „[...] okrem doslovného prekladu mi... dal dr. Felix množstvo poznámok, vysvetlujúcich každý verš, ba takmer každé slovo a jeho súvis s celou skladbou i d’alším básnickým dielom[...]“. Týkalo sa to pozoruhodného množstva materiálu k Danteho biografii a dielu, nehovoriac o tom, že plody takejto spolupráce sa odzrkadlili, ako hovorí Jana Truhlářová pri analýze textových interpretácií a prekladatel'skej metódy J. Felixa, aj „v súvislosti s prekladom Vel'kého testamentu. Malého testamentu a Kodicilu F. Villona v podaní J. Kostru, J. Smreka a I. Mojíka“ (TRUHLÁŘOVÁ 2014: 186; in: JOZEF FELIX (1913-1977) a cesta $k$ modernej slovenskej romanistike).

Textologický záujem sa teda u Felixa obracal aj k takým oblastiam, ktoré priamo nesúviseli s prekladatel’skými problémami prozaického diela, ale z iných zorných uhlov dokreslovali alebo doplňovali vedeckejšiu stránku veršových výskumov M. Bakoša, V. Kochola, V. Turčányho alebo A. Popoviča. Dochádzalo tak k vzácnej symbióze viacerých aspektov, bezprostredne oslovujúcich mladú generáciu slovenských bádatel’ov i spisovatelov.

Podobný multidimenzionálny prístup sa nakoniec odrazil aj v mojej vlastnej výskumnej práci, v ktorej som si v tých časoch z podnetu môjho školitela Jozefa Felixa zvolil za tému dizertačnej práce slovenské preklady poézie francúzskeho neosymbolistu Paula Claudela (porov. Štýl prekladu. Vývinovo-teoretická a kritická analýza slovenských prekladov Paula Claudela; výskum bol zavŕšený už v r. 1975, avšak pre známe príčiny knižne vyšiel až v r. 1997). Už vzhl’adom 
na to, že uvedené preklady odzrkadlovali mnohé z dejín slovenskej poézie, otvárali sa predo mnou mnohé netušené obzory, aj teoretické, a predovšetkým vývinové. Základný podnet $\mathrm{v}$ tomto úsilí predstavoval vnútroliterárny výskum slovenského verša, ako ho už dávnejšie uskutočnil $\mathrm{M}$. Bakoš. $\mathrm{K}$ tomu pristúpila rovnocenná požiadavka vyrovnat sa s takto postavenou priekopníckou medziliterárnou témou vo vztahahu k západným literatúram aj kriticky, pri paralelnom štúdiu viacerých prác francúzskych teoretikov verša. Musím povedat', že v tom mi najmä v začiatkoch pomocnú ruku podal práve Jiři Levý. Dôležitý bol najmä jeho poznatok o metrickej nezhode francúzskeho, českého a teda i slovenského verša, obsiahnutý v tvrdení: „Francouzský verš se převádí tradičně jambem. Vývoj tohoto př̀kladového jambu sa nelišil od vývoje jambického verše původní poezie a ve svých historických obměnách přesněji vystihoval jednou tu, podruhé zase jinou kompoziční vlastnost francouzského verše“ (LEVÝ 1963: 173).

Týmto tvrdením vlastne plodne usmernil môj konkrétny výskum slovenských prekladov francúzskeho básnika. V ňom sa totiž moja komparácia priamo odvíjala z poznania jazykovej nezhody alebo inkompatibility obidvoch veršových systémov. Jedným z d’alších impulzov boli Levého exaktné zistenia ohl’adne významovej hustoty francúzskeho a českého verša, vrátane d’alších významných výsledkov francúzskych teoretikov (M. Grammonta, P. Guirauda, a neskôr najmä J. Cohena) francúzskeho veršovania, napríklad v súvislosti s rýmovým slovníkom alebo so sylabickou povahou francúzskeho verša. To všetko podstatnou mierou prispelo ku konfrontácii Bakošových teoreticko-praktických východísk s Levého štruktúrne osobitým prienikom do všeobecných jazykových základov českého a francúzskeho veršovania.

Priamym odrazom, čiastočne aj pomocou štatistických ukazovatel’ov, bol konkrétny rozbor i porovnanie prekladatel’skej metódy viacerých slovenských prebásňovatel'ov Claudela (E. Boleslava Lukáča, P. Gašparoviča Hlbinu, J. Haranta, K. Strmeňa). U väčšiny z nich sa totiž prejavila bezprostredná závislost’ od metrických alebo prozodických noriem dobovej slovenskej poézie. Zároveň to bolo možné čiastočne vypozorovat prostredníctvom komparatívneho pohladu na ich vlastnú tvorbu. Tlak inakosti Claudelovho rytmicky i syntakticky uvol’neného „biblického versetu“, sledovaný v súvislosti so štruktúrnymi princípmi francúzskeho a slovenského jazyka, bol v prvej časti mojej práce dokumentovaný viacerými výraznejšími odchýlkami oproti predlohe. Vzácnu oporu som pri tom nachádzal v Bakošovej koncepcii ústrednej úlohy rytmu v premenlivej súhre zvukovo-eufonických, intonačno-syntaktických a sémantických komponentov porovnávaných veršov. Treba zdôraznit, že Levého názory na prekladový jamb 
potvrdzovali predovšetkým prvé preklady francúzskeho básnika, ktoré zásluhou Emila Boleslava Lukáča vznikli už v medzivojnovom období (Cesta krížová 1924, 1929, 1948, 1949; Verše z vyhnanstva 1933). Dôsledné dodržiavanie metrickej osnovy jambu, ako potvrdil celistvý štruktúrny rozbor, vyústilo u slovenského básnika do viacerých výraznejších posunov oproti originálu.

Vzt’ahovalo sa to najmä na rozsiahlu básnickú skladbu Cesta krížová. Jej symbolicko-epický a zároveň lyrický charakter, vyjadrený u Claudela s mierou a ironickým odstupom, nadobudol v Lukáčovom preklade znaky artistnej doslovnosti sprevádzanej esteticky príznakovými slovami ludového zafarbenia alebo neologizmami, čo priamo odrážalo ovplyvňovanie výrazovými prostriedkami hviezdoslavovských básnikov. Ako sa ukázalo, určujúce pôsobenie jambického metrického pôdorysu sa prejavovalo častým emfatickým dôrazom na prvej slabike slova, mnohými básnickými licenciami, frekventovanejším výskytom lexikálno-syntaktických paralelizmov, významovou zataženost’ou rýmoviek a podobne. So zretel'om na štruktúrne zákonitosti jazyka francúzštiny a slovenčiny bolo pre mňa objavným zistením, že v niektorých neutrálnejšie ladených básňach (Magnificat) to viedlo $\mathrm{k}$ očividnému narúšaniu homogénnosti veršov, ku konfliktu medzi metrom a významom, medzi vetou a veršom. Dialektická povaha štruktúrnej metódy pomohla odhalite že čím bola Claudelova veta prozaickejšia, tým sa Lukáčovo rytmické cítenie vzpieralo možnosti adekvátne vyjadrit estetické hodnoty originálu. Preto bolo nakoniec pochopitelné, že skutočné kvality prekladatel'skej poézie a poetiky mohli s obdivuhodným majstrovstvom vystúpit na povrch v tých Claudelových básňach (Kyrie Eleison), ktorých zložitú, tradične ustrojenú paralelnú syntaktickú stavbu vedel Lukáč reprodukovat’ s bravúrnou virtuozitou, dosiahnutím želatel’nej estetickej súdržnosti veršov.

Ako vidiet', štruktúrna poetika, do značnej miery v duchu Levého postulátov, môže pri dôkladnej textovej analýze nachádzat̉ plnohodnotné uplatnenie. Organickou súčastou je prirodzený dôraz na typologickú, druhovo-slohovú podstatu poézie, podla miery zastúpenia lyrického a epického živlu v jednotlivých básňach. Na tomto základe sa u mňa vyvíjal i rozbor vývinovo neskorších slovenských prekladov francúzskeho symbolistu. Vd’aka tomu som mohol dospiet’ k d’alším, nielen logicky dokázatel’ným poznatkom. Týkali sa napríklad lyrického charakteru Claudelových Veršov z vyhnanstva, ktorých pravidelná jambická stopovost vcelku zodpovedala výrazovým požiadavkám originálu.

Obdobný rozbor sa javil naplno funkčný aj pri vnímaní kraskovského daktylotrocheja, ktorý v zhode $s$ brémondovským ideálom čistého duchovného výrazu v básni Svätý Pavol uplatnil P. Gašparovič Hlbina. Napriek tomu, že v da- 
nom prípade bolo možné zaznamenat výraznejší odklon od autorovej poetiky, preložené verše pôsobili na každom mieste pri nezávislejšom pohlade esteticky koherentne. Pravda, tu bolo treba vziat do úvahy, že syntakticky zhodné metrické klauzuly spôsobovali významovo nenásilné rozširovanie originálu, a najmä z toho vyplývajúcu skutočnost', že oproti objektivistickej metóde M. Bakoša a čiastočne J. Levého bolo nutné zapojit do výskumu subjektívne vnímanie rytmicko-melodickej línie veršov (podla mexického básnika Octavia Paza je „význam dietatom zvuku“; pozri knihu Tiene diel, Sombras de obras 1983), intuitívne cítenie rešpektujúce deklamačno-akustické hodnoty básnenia.

Takúto požiadavku vyslovil na Slovensku moderný básnik Štefan Krčméry (BAKOŠ 1966: 62-69), u ktorého vnímanie básnického rytmu počítalo tiež s prirodzeným presúvaním prízvukov v prúde vety, i ked' melodicky citlivý prístup vcelku neodporuje Bakošovým štatisticky overitel’ným zisteniam.

Vyústením tvorivého uplatnenia štruktúrno-historickej poetiky boli poznatky o oneskorenom vývine slovenskej poézie v porovnaní s francúzskou, čo sa dalo v druhej časti mojej práce, zameranej na odhalenie širšej motivovanosti prekladatel'ských posunov, dokázat’ na osobitnom symbolickom pláne vzhladom na univerzálne hodnoty Claudelovej poézie. To všetko završovali kulturologicky relevantné poznatky týkajúce sa mentálnej odlišnosti nielen básnických generácií u obidvoch národov, slovenského a francúzskeho, cez osvetlenie predchádzajúcich vývinových štádií francúzskej poézie (najmä poetiky Mallarmého a Rimbauda). Ich podnety umožnili francúzskemu katolíckemu básnikovi cez programové dielo Art poétique dospiet’ k vytúženej coincidentia oppositorum, $\mathrm{k}$ odhaleniu skrytého súladu medzi viditel’nými a neviditel'nými vecami, medzi životom a večnostou. Napokon nie je bez zaujímavosti, že požiadavka kongeniálnej „vernosti“ sa, podobne ako u českého prebásňovatella Claudelovho biblického versetu Otta Františka Bablera (Krížovú cestu po B. Reynekovi uverejnil v r. 1937, ) naplnila až v slovenskom preklade tohto diela vd’aka K. Strmeňovi (1954).

Vzhl’adom na stručnost’ môjho príspevku, zameraného na podnetnosť českých a slovenských verzologických výskumov pre konkrétny medziliterárny rozbor, nebudem sa na tomto mieste zaoberat' d’alšími otvárajúcimi sa perspektívami podobnej komparácie. Z mnohorakých podnetov J. Levého, M. Bakoša, J. Mukařovského alebo A. Popoviča by sa dali uviest́ viaceré príklady, ktoré dosvedčujú vzácne zblíženie príbuzných, hoci v Čechách i na Slovensku navzájom odlišných, a doplňujúcich prekladatel'ských poetík. Preto možno len l’utovat', že v dôsledku neblahého zásahu normalizácie nastáva v priebehu sedemdesiatych 
rokov u nás násilné prerušenie tvorby štruktúrno-vývinových bádatel’ských projektov. Nakoniec sa žiada zdôraznit, že práve A. Popovič v poslednej štúdii svojej knihy Preklad a výraz pod názvom Významová hustota rytmických posunov v preklade. Petőfi a Hviezdoslav najbezprostrednejšie nadviazal na Levého koncepciu štruktúrnej rozdielnosti jazykov. Vykonal to pri rozbore mad’arčine prirodzenej časomernosti a jej pôsobenia na preklady slovenského básnika (POPOVIČ 1968: 167-220).

Pravdaže, v podobnom svetle by vyzneli i d’alšie komparácie týkajúce sa napríklad českého, slovenského a španielskeho verša, čomu som sa detailnejšie venoval v niektorých teoreticko-analytických štúdiách (porov. Interdisciplinárnost'v symbióze literárnej vedy a umenia 2012, II. 2016). Napriek pretrvávajúcim prekážkam i vonkajším obmedzeniam patrím nad’alej k tým pokračovatel’om veršových výskumov, ktorí sú presvedčení, že štruktúrno-historická poetika, mnohostranne uplatňovaná za cenu dôkladnej, dnes bežne nedoceňovanej jazykovej a teoretickej prípravy, nestratila svoj pôvodný metodický zmysel. Ved' nejde iba o úzku platformu jazykového a medzijazykového poznávania i sebapoznávania. Uvedený ciel' podl’a môjho názoru vonkoncom neprotirečí ani natol'ko proklamovanému, a prakticky $\mathrm{v}$ mnohom $\mathrm{v}$ súčasnosti nenaplnenému kultúrnemu dialógu medzi národmi.

Keby dnes Jiří Levý žil, i ked’, myslím si, žije práve dnes i nad’alej (uvedomujeme si to?), určite by sa podpísal pod môj názor vyslovený v závere mojej štúdie Style de la traduction poétique. Aby ma nebodaj niekto neupodozrieval z neakceptovatelných antiglobalizačných zámerov, zámerne ho zacitujem v pôvodnom znení vo francúzštine: „La poétique structurale et historique, dont on s'est servi à l'analyse de quelques traductions slovaques de la poésie de Paul Claudel, a pour rôle d'observer et de circonscrire les textes comparés. Comme elle donne, parallèlement, une bonne occasion d'apprécier la valeur esthétique des oeuvres traduites qui sont, on l'a bien vu, un fruit de l'évolution littéraire et culturelle différente. Ce faisant, l'exégète ne doit pas être toujours soumis aux exigences purement logiques d'une science exacte, mais en respectant aussi les méthodes intuitives de la connaissance, il peut se retrouver le plus près possible de la perception de celui à qui la poésie offre - croyons que désormais - une sorte d'enchantement" (FRANEK 2016: 212). ${ }^{1}$

1) Štruktúrno-historická poetika, ktorú sme použili pri analýze niektorých slovenských prekladov z poézie Paula Claudela, má za úlohu pozorovat’ a opísat porovnávané texty. Súbežne ponúka príležitost' zhodnotit’ estetickú hodnotu preložených diel, ktoré sú - ako sme jasne videli - plodom odlišného literárno-kultúrneho vývinu. Pri tejto práci exegéta nemusí vždy podliehat’ čisto logickým požiadavkám exaktnej literárnej vedy, ale rešpektujúc tiež in- 


\section{PRAMENE}

CLAUDEL, Paul

1957 Oeuvre poétique (Paris: Gallimard)

LUKÁČ, Emil Boleslav

1929 Cesta krížová (Le chemin de la Croix) (Praha: Pražské nakladatelství L. Kuncíře)

1933 „Verše z vyhnanstva (Vers d'exil)“, „Kyrie Elejson (Kyrie Eleison)“, in Trofeje (Turčiansky sv. Martin:

Matica slovenská)

1947 „Magnificat (Magnificat)“, in Záhrada útechy (Trnava: Spolok sv. Vojtecha)

HLBINA, Pavol Gašparovič

1943 „Svätý Pavol (Saint Paul)“, in O Tebe spieva zem (Trnava: Spolok sv. Vojtecha)

\section{LITERATÚRA}

BAKOŠ, Mikuláš

1966 Vývin slovenského verša od školy Štúrovej, 3. dopl. vydanie (Bratislava: VSAV)

1969 Avantgarda 38. Štúdie, články, dokumenty (Bratislava: Slovenský spisovatel')

1969 Literárna história a historická poetika (Bratislava: Ústav svetovej literatúry a jazykov)

2016 Mikuláš BAKOŠ a moderná literárna veda. Zostavil, personálnu bibliografiu a kalendárium napísal

D. Teplan (Nitra: Univerzita Konštantína Filozofa)

CLAUDEL, Paul

1933 Art poétique (Paris: Mercure de France)

1953 Réflexions sur la poésie (Paris: Gallimard)

ĎURIŠIN, Dionýz

1967 Problémy literárnej komparatistiky (Bratislava: VSAV)

\section{FELIX, Jozef}

1987 Cesty k vel'kým. Pohl’ady na európsku literatúru (Bratislava: Slovenské vydavatel’stvo krásnej literatúry)

1962 „Hugov Satyr v slovenčine“, Slovenské pohl’ady 78, č. 6, 1962, s. 64-70

1970 Modernita súčasnosti (Bratislava: Slovenský spisovatel')

2014 JOZEF FELIX (1913-1977) a cesta k modernej slovenskej romanistike. Jana Truhlářová (ed.) (Bratislava: Veda)

tuitívne metódy poznania, môže sa opätovne čo najbližšie ocitnút vnemu toho, komu poézia poskytuje - verme, že i nad’alej - akýsi druh očarenia. 
Ladislav Franek

Verzologické výskumy v Čechách a na Slovensku (Pocta Jiřímu Levému)

FRANEK, Ladislav

1997 Štýl prekladu. Vývinovo-teoretická a kritická analýza slovenských prekladov Paula Claudela (Bratislava: Veda)

2005 Modernita románskych literatúr (Bratislava: Veda)

2012 Interdisciplinárnost' v symbióze literárnej vedy a umenia (Bratislava: Veda)

2016 Interdisciplinárnost' v symbióze literárnej vedy a umenia II (Bratislava: Veda)

LEVÝ, Jiř́

1957 České theorie prekladu (Praha: SNKLHU)

1963 Umění přkkladu (Praha: Československý spisovatel)

1966 „Sémantika verše“, Litteraria IX, Bratislava, O literárnej avantgarde, s. 17

MUKAŘOVSKÝ, Jan

1948 Kapitoly z české poetiky I. Obecné věci básnictví (Praha: Svoboda)

1971a Cestami poetiky a estetiky (Praha: Československý spisovatel)

1971b Studie z poetiky (Praha: Odeon)

1995 Básnická sémantika (Praha: Carolinum - Univerzita Karlova)

POPOVIČ, Anton

1968 Preklad a výraz (Bratislava: VSAV)

1970 Štrukturalizmus v slovenskej vede, Dejiny, texty, bibliografia (1931-1949) (Martin: Matica Slovenská)

1971 Poetika umeleckého prekladu (Bratislava: Tatran)

TURČÁNY, Viliam

1960/1961 „K poetike Hviezdoslavových prekladov“, Slovenská literatúra 7, č. 4, s. 413-438; 8, č. 1, s. 38-46

Prof. PhDr. Ladislav Franek, CSc., ladislav.franek@savba.sk, Ústav svetovej literatúry Slovenskej akadémie vied, Bratislava, Slovenská republika / Institut of World Literature of the Slovak Academy of Sciences, Bratislava, Slovak Republic 